\title{
JUURNAL.RU
}

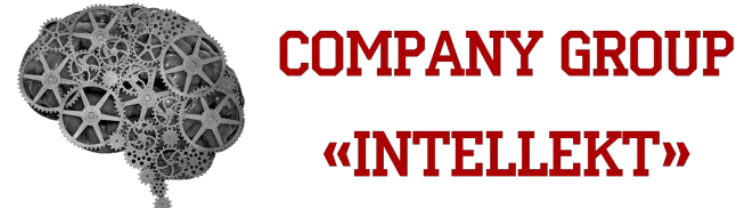

Холмогорова Н.Ю. Нижегородская Академия МВД России Нижний Новгород, Россия

doi: 10.18411/lj2016-3-104

\section{Практика применения досудебного соглашения о сотрудничестве в уголовном судопроизводстве России}

Рассматриваемый правовой институт, на наш взгляд, не получил широкого распространения в практике правоприменителя. Так, с момента внесения изменений в Федеральное законодательство, ${ }^{1}$ по настоящее время сотрудниками следственного аппарата МВД по Удмуртской Республике заключено незначительное число досудебных соглашений о сотрудничестве.

Изучая судебно-следственную практику по досудебному соглашению о сотрудничестве, данный институт не нашел широкого применения не только в МВД по Удмуртской Республике, но и в других регионах России. Так, в 2014 году Липецким областным судом проведено изучение практики применения судами области особого порядка судебного разбирательства уголовных дел при заключении досудебного соглашения о сотрудничестве за 2013 год, за который судами было рассмотрено 31 уголовное дело указанной категории. Обобщение показало, что применение положений главы 40.1 УПК РФ, регулирующей особый порядок принятия судебного решения при заключении досудебного соглашения о сотрудничестве, вызывает немало трудностей, при этом допускаются ошибки, как на досудебной стадии, так и на стадии рассмотрения

${ }^{1}$ Федеральный закон РФ от 29 июня 2009 года № 141-Ф3 «О внесении изменений в Уголовный кодекс Российской Федерации и Уголовно-процессуальный кодекс Российской Федерации» // Российская газета. - 2009. - № 121, который ввел в УПК РФ главу 40.1, предусматривающую особый порядок принятия судебного решения при заключении досудебного соглашения о сотрудничестве. 
дела судом² ${ }^{2}$ В 2013 году судами Республики Хакасия рассмотрено 24 уголовных дела в отношении 24 лиц, с которыми было заключено досудебное соглашение о сотрудничестве. Анализ судебных решений позволяет сделать вывод, что из рассмотренных уголовных дел только 1 дело о преступлении в сфере экономической деятельности (ст. 171.2 УК РФ) ${ }^{3}$. Районными и городскими судами Самарской области в 2014 году рассмотрено 5658 уголовных дел, особый порядок судебного производства в порядке гл. 40.1 УПК РФ применялся по 12 делам $^{4}$, что составило 0,2 \% от общего числа рассмотренных дел. Согласно статистическим данным Верховного суда Республики Саха (Якутия), судами республики за 2012 год рассмотрено 21 дело в особом порядке принятия судебного решения при заключении досудебного соглашения о сотрудничестве. В 2013 году судами республики рассмотрено 55 уголовных дел указанной категории ${ }^{5}$. Кроме того, следует указать о случаях отмены и изменения решений суда в Нижегородской области за первое полугодие 2014 года по уголовным делам, рассмотренным в порядке главы 40.1 УПК Р $\Phi^{6}$.

Не смотря на указанную статистику ряд ученых-процессуалистов придерживаются мнения о благополучном использовании досудебных соглашений на практике ${ }^{7}$. На наш взгляд, рассматриваемый институт применяется, но не вошел в повседневную практику следственного аппарата МВД России.

Представляется, что одной из проблем является взаимодействие следователя и прокурора на этапе заключения и реализации досудебного соглашения о сотрудничестве. В процессе правоприменения прокурорами

\footnotetext{
${ }^{2}$ http://oblsud.lpk.sudrf.ru/modules.php?id=2454\&name=docum_sud

${ }^{3}$ Обзор практики рассмотрения судами уголовных дел в особом порядке, предусмотренном главой 40.1 УПК РФ // http://vs.hak.sudrf.ru/modules.php?name=docum_sud\&id=220

${ }^{4} \mathrm{http}: / /$ oblsud.sam.sudrf.ru/modules.php?did=453\&name=press_dep\&op=1

${ }^{5}$ Обобщение за 2013 г.: досудебное соглашение о сотрудничестве (в порядке главы 40-1 УПК РФ) // http://vs.jak.sudrf.ru/modules.php?name=docum_sud\&id=489

${ }^{6}$ http://oblsudnn.ru/index.php/obzory-sudebnoj-praktiki-2/1100-obobshchenie-sudebnoj-praktikivozvrashcheniya-ugolovnykh-del-prokuroru-nizhegorodskim-oblastnym-sudom-v-poryadke-st-237-upk-rf-za-2006-god5

7 Кубрикова М.Е. Актуальные вопросы института досудебного соглашения о сотрудничестве: Автореф. дис... канд. юрид. наук. - Челябинск, 2013. - 25 с.
} 
необоснованно отказывается в удовлетворении ходатайства обвиняемых о заключении досудебного соглашения о сотрудничестве, либо возникают трудности во взаимодействии при решении именно данного вопроса. В качестве примеров можно привести уголовные дела, находившиеся в производстве СЧ СУ МВД по Удмуртской Республике, по расследованию преступлений, совершенных организованными преступными группами. Так, было отказано даже в попытке обсудить на межведомственных совещаниях вопрос о возможном заключении досудебного соглашения о сотрудничестве. В первом случае, уголовное дело расследовалось в отделе по расследованию преступлений общеуголовной направленности СЧ СУ МВД по Удмуртской Республике. По данному уголовному делу привлекалось к уголовной ответственности 6 человек, усматривалось 85 преступных эпизодов по ч. 4 ст. 159 УК РФ. Данное уголовное дело по обвинению Ш. и других соучастников направлено в суд в особом порядке, со сроком предварительного расследования более 16 месяцев ${ }^{8}$.

Во втором случае, уголовное дело находилось в производстве отдела по расследованию преступлений экономической направленности СЧ СУ МВД по Удмуртской Республике, по делу обвинение предъявлялось 11 участникам, вменялось 87 преступных эпизодов по ч. 4 ст. 159 УК РФ. Данное уголовное дело по обвинению Б. и других соучастников направлено в суд в общем порядке, со сроком предварительного расследования более 27 месяцев ${ }^{9}$.

Указанные уголовные дела представляли сложность в расследовании, обусловленную большим количеством свидетелей, необходимостью исследования множества доказательств, проведением очных ставок со многими участниками. Отказ прокуратуры в возможном заключении досудебного соглашения о сотрудничестве с обвиняемыми мотивирутся необходимостью добыть достаточное количество доказательств сотрудниками предварительного

\footnotetext{
${ }^{8}$ Уголовное дело № 1-243 (03/226) // Архив Завьяловского районного суда Удмуртской Республики.

9 Уголовное дело № 1-348/13 (92/523) // Архив Первомайского районного суда г. Ижевска Удмуртской Республики.
} 
следствия, исключая возможную дачу признательных показаний обвиняемыми. Возможно, это является положительным моментом для развития профессиональных качеств следователя, но нарушается принцип разумности судопроизводства, сроки следствия, растут процессуальные издержки.

Следует отметить и положительный момент. Так, при расследовании уголовного дела, находившегося в производстве отдела по расследованию преступлений экономической направленности СЧ СУ МВД по Удмуртской Республике, по которому привлекалось к ответственности 29 участников, вменялось 5 преступных эпизодов по ч. 4 ст. 159 УК РФ, а также иные составы преступлений, было заключено досудебное соглашение о сотрудничестве с одним обвиняемым. Данное уголовное дело по обвинению 3. и других соучастников направлено в суд в общем порядке, со сроком предварительного расследования 22 месяца $^{10}$. При заключении досудебного соглашения в данном случае, сроки следствия по основному делу непременно уменьшились, доказательственная база расширилась, процессуальные издержки уменьшились, статистические показатели (важность которых не стоит умалять при работе в МВД) улучшилась, что является непременно положительным опытом, по нашему мнению.

На наш взгляд, правовой институт досудебного соглашения о сотрудничестве направлен на противодействие организованным формам преступности путем привлечения правоохранительными органами к сотрудничеству лиц, состоящих в организованных группах и преступных сообществах, на условиях сокращения им уголовного наказания и распространения на них мер государственной защиты. В настоящее время данный институт, зачастую, применяется при расследовании преступлений общеуголовной направленности, не представляющих принципиальной сложности в расследовании. Это не являлось целью введения досудебного

10 Уголовное дело № 03/1019 // Архив Индустриального районного суда г. Ижевска Удмуртской Республики. 
соглашения о сотрудничестве в российское законодательство, и не соответствует стратегии его развития ${ }^{11}$, упомянутой Генеральным прокурором России.

11 Чайка Ю.Я. Под надзором // Российская газета. - 2008. - № 4596. 